Trinity University

Digital Commons @ Trinity

\title{
8-2012
}

\section{Holocene Earthquakes and Late Pleistocene Slip-Rate Estimates on the Wassuk Range Fault Zone, Nevada}

\author{
J. M. Bormann
}

Benjamin E. Surpless

Trinity University, bsurples@trinity.edu

M. W. Caffee

S. G. Wesnousky

Follow this and additional works at: https://digitalcommons.trinity.edu/geo_faculty

Part of the Earth Sciences Commons

\section{Repository Citation}

Bormann, J. M., Surpless, B. E., Caffee, M. W., \& Wesnousky, S. G. (2012). Holocene earthquakes and late Pleistocene slip-rate estimates on the Wassuk range fault zone, Nevada. Bulletin of the Seismological Society of America, 102(4), 1884-1891. doi: 10.1785/0120110287

This Article is brought to you for free and open access by the Geosciences Department at Digital Commons @ Trinity. It has been accepted for inclusion in Geosciences Faculty Research by an authorized administrator of Digital Commons@ Trinity. For more information, please contact jcostanz@trinity.edu. 


\title{
Short Note
}

\section{Holocene Earthquakes and Late Pleistocene Slip-Rate Estimates on the Wassuk Range Fault Zone, Nevada}

\author{
by Jayne M. Bormann, ${ }^{*}$ Benjamin E. Surpless, Marc W. Caffee, and Steven G. Wesnousky
}

\begin{abstract}
The Wassuk Range fault zone is an 80-km-long, east-dipping, high-angle normal fault that flanks the eastern margin of the Wassuk Range in central Nevada. Observations from two alluvial fan systems truncated by the fault yield information on the vertical slip rate and Holocene earthquake history along the range front. At the apex of the Rose Creek alluvial fan, radiocarbon dating of offset stratigraphy exposed in two fault trenches shows that multiple earthquakes resulted in $7.0 \mathrm{~m}$ of vertical offset along the fault since $\sim 9400$ cal B.P. These data yield a Holocene vertical slip rate of $0.7 \pm 0.1 \mathrm{~mm} / \mathrm{yr}$. The south trench exposure records at least two faulting events since $\sim 9400$ cal B.P., with the most recent displacement postdating $\sim 2810$ cal B.P. The north trench exposure records an $\sim 1 \mathrm{~m}$ offset between $\sim 610$ cal B.P. and A.D. $\sim 1850$, a $1.3-\mathrm{m}$ minimum offset prior to $\sim 1460$ cal B.P., and one earlier undated earthquake of a similar size. Variations in stratigraphy and limited datable material preclude a unique correlation of paleoevents between the two trenches. Approximately $25 \mathrm{~km}$ north, the range-front fault has truncated and uplifted a remnant of the Penrod Canyon fan by $>40 \mathrm{~m}$ since the surface was deposited $\sim 113 \mathrm{ka}$, based on cosmogenic dating of two large boulders. These data allow an estimate of the minimum late Pleistocene vertical slip rate at $>0.3-0.4 \mathrm{~mm} / \mathrm{yr}$ for the Wassuk Range fault zone.
\end{abstract}

Online Material: Tables summarizing radiocarbon and cosmogenic analyses, photos of rocks sampled for cosmogenic analyses, and figures summarizing cosmogenic exposure age estimates.

\section{Introduction}

The Wassuk Range fault zone is an east-dipping normal fault that strikes north-northwest for a distance of over $80 \mathrm{~km}$ along the eastern margin of the Wassuk Range and forms the western boundary of the Walker Lake basin (Fig. 1). Thermochronologic analysis suggests that rapid extensional deformation and uplift of the Wassuk Range occurred between $\sim 15$ and $12 \mathrm{Ma}$, with renewed uplift along the present-day, high-angle, range-front fault beginning $\sim 4 \mathrm{Ma}$ (Stockli et al., 2002; Surpless et al., 2002). The Wassuk Range is a major tectonic feature in the central Walker Lane, a complex zone of transtensional faulting that separates the extending Basin and Range province from the rigid Sierra Nevada block and accommodates up to $10 \mathrm{~mm} / \mathrm{yr}$ of Pacific-North American relative right-lateral plate motion (e.g.,

\footnotetext{
*Also at Nevada Geodetic Laboratory, Nevada Bureau of Mines and Geology, University of Nevada, Reno, Reno, Nevada 89557.
}

Thatcher et al., 1999; Oldow et al., 2001; Bennett et al., 2003; Hammond and Thatcher, 2007).

Strain in the central Walker Lane is strongly partitioned into a zone of shear-dominated deformation to the east of the Walker Lake basin and extension-dominated deformation to the west (e.g., Oldow, 2003; Wesnousky, 2005; Surpless, 2008). Previous geologic studies show displacement along the Wassuk Range fault zone is predominantly normal (e.g., Dilles, 1993; Stockli et al., 2002; Wesnousky, 2005; Surpless, 2011), so the range-bounding fault is ideal to investigate vertical slip rates related to extensional deformation. We report observations from two locations along the Wassuk Range that refine the earthquake history and slip rate along the range-front fault (Fig. 1). At Rose Creek, two trenches excavated across the fault yield information about the size and timing of Holocene earthquakes and an estimate of the Holocene slip rate. At Penrod Canyon, cosmogenic dating of two large boulders on an uplifted, abandoned 


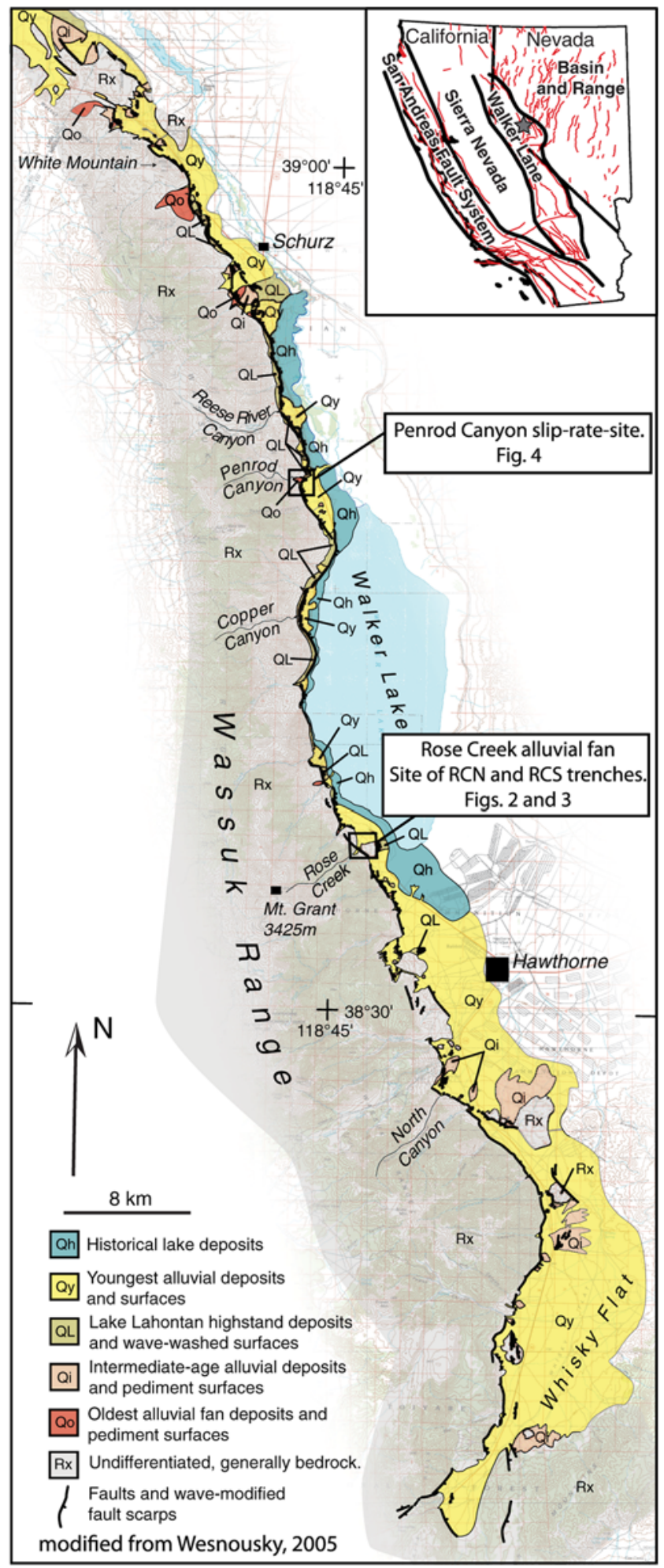

Figure 1. Surficial geologic map of the Wassuk Range fault zone. Faults are shown in relation to Quaternary surficial deposits. Open black boxes mark the locations of the Rose Creek and Penrod Canyon study sites. Map is reprinted and adapted from Wesnousky (2005). Inset map shows the location of the Wassuk Range (star) in relation to the major faults (modified from the U.S. Geological Survey, et al., 2006 database; see Data and Resources section) and tectonic provinces in Nevada and California. The color version of this figure is available only in the electronic edition. fan remnant yields an estimate of the late Pleistocene vertical slip rate. These data will improve regional seismic hazard models for a fault that previously lacked detailed paleoseismic constraints.

\section{Rose Creek Alluvial Fan}

Rose Creek drains the highest portion of the Wassuk Range and has produced a large fan on the eastern flank of the range front (Fig. 1). The Wassuk Range fault zone cuts the apex of the Rose Creek fan at an elevation of $\sim 1525 \mathrm{~m}$, well above the $\sim 1330$-m $\sim 15,500$-cal B.P. late-Pleistocene Lake Lahontan highstand (Fig. 1; Adams and Wesnousky, 1999; highstand age calibrated by Briggs and Wesnousky, 2004). The fault is marked by scarps with vertical separations of 1-7 $\mathrm{m}$ in Holocene alluvial fan deposits (Fig. 2). We

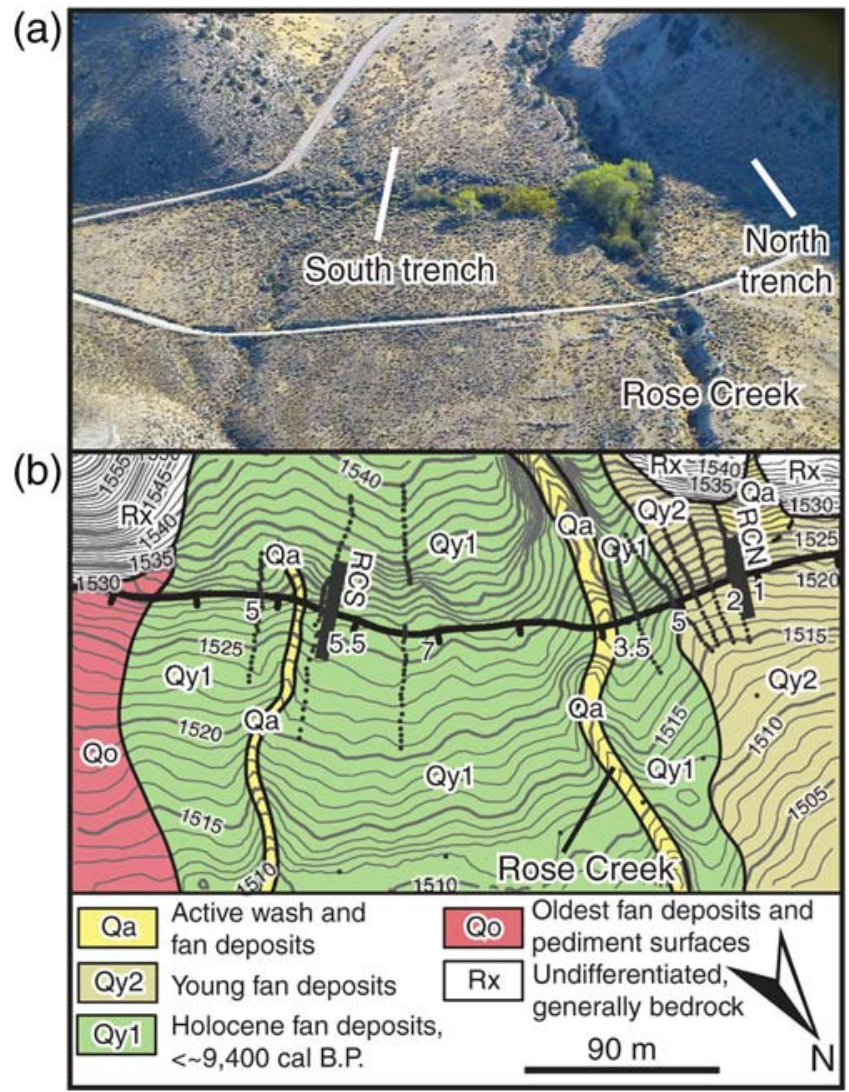

Figure 2. Rose Creek alluvial fan paleoseismic and slip-rate site. See Figure 1 for site location. (a) Aerial photograph showing the location of the north (RCN) and south (RCS) trenches along the fault scarp in relationship to Rose Creek. (b) Surficial geologic map of the mouth of Rose Canyon: mapping, based on field observations and low-sun-angle air photos; modified from Demsey (1987). The fault is marked as a black line with ticks on the down-thrown side. Trench locations for RCN and RCS are indicated with thick lines. Numerical annotations indicate vertical separations measured from surveyed fault scarp profiles (small circles). The 1-m topographic basemap was constructed from a Light Detection and Ranging (LiDAR)-derived digital elevation model of Walker Lake (Smith, 2008). The color version of this figure is available only in the electronic edition. 
excavated two trench exposures to quantify the timing, displacement, and recurrence of slip on the fault.

\section{Rose Creek North Trench}

The Rose Creek north ( $\mathrm{RCN})$ trench cut perpendicularly across a 1-m scarp in the Qy2 alluvial fan surface northwest of Rose Creek (Fig. 2). The 20-m-long trench exposed alluvial fan gravels that are offset across several normal fault strands (Fig. 3a). At the base of the footwall, unit 1 is composed of sandy alluvial gravel overlain by a coarse debrisflow deposit and younger sandy alluvial gravel. Unit 2 is scarp-derived colluvium and fissure fill composed of loosely consolidated pebbles, cobbles, and small boulders in a sandy matrix. A coherent block of the coarse debris-flow member of unit 1 is entrained in the unit 2 fissure fill. Soil is not pre- sent or preserved on the surfaces of either unit 1 or 2 . Unit 3 is a coarse debris-flow deposit that overlies unit 2. Soil formation on unit 3 is limited to development of a stage-1 carbonate. Fault strand B offsets footwall units 1, 2, and 3. Units 2 and 3 are further offset and truncated by fault strand A. In the hanging wall, unit 4 is composed of alternating layers of fine and coarse alluvium and lacks soil development. It is similar in composition to footwall units 1,2 , and 3, though correlation of individual beds across the fault zone is ambiguous. Unit 5 is a wedge-shaped package of east-dipping and upward-fining scarp-derived colluvium that overlies unit 4. A fissure extending downward from the base of the wedge is filled with unit 5 sands and gravels (subunit $\left.5^{\prime}\right)$. Unit 5 lacks soil development and is overlain by a charcoal-bearing alluvial deposit (unit 6). Unit 6 is composed of brownish-tan, sandy matrix-supported fan gravels that are

(a)

$\mathrm{RCN}-\mathrm{T} 1$ \& $\mathrm{T} 2$

Samples from a reworked tephra deposit regionally correlated with Mono Craters volcanism $600-2000{ }^{14} \mathrm{C}$ B.P.

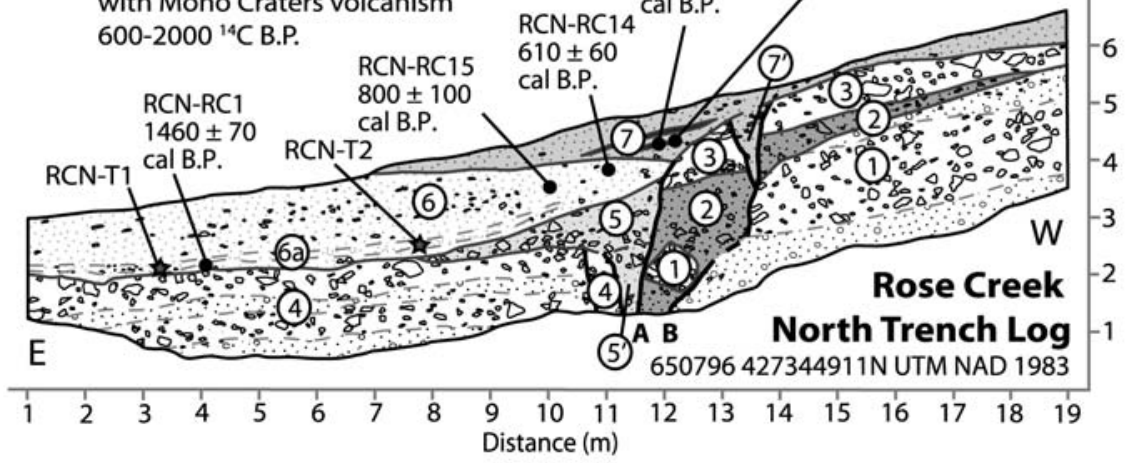

Unit 1 - Alternating fine- and coarse-grained alluvium

Unit 2 - Colluvium and fissure fill

Unit 3 - Coarse debris-flow deposit

$\widehat{\xi}$ Unit 4-Alternating fine- and coarse-grained alluvium/colluvium?

Unit 5 - Colluvium and fissure fill $\left(5^{\prime}\right)$

Unit 6 - Fine-grained alluvial gravels, tephra and charcoal-bearing lens (6a)

Unit 7 - Colluvium, fissure fill ( $\left.7^{\prime}\right)$, and finegrained alluvium

(b) Unit 1 - Organic rich debris flow deposit Unit 5-Alluvial fan slope-wash

Unit 2 - Coarse tabular debris flow deposits Unit 6-Tephra bearing fine-grained fluvial

Unit 3 - Massive colluvium package grading eastward into tabular beds deposit

Unit 4 - Fissure fill

Unit 7 - Slope-wash and aeolian deposits

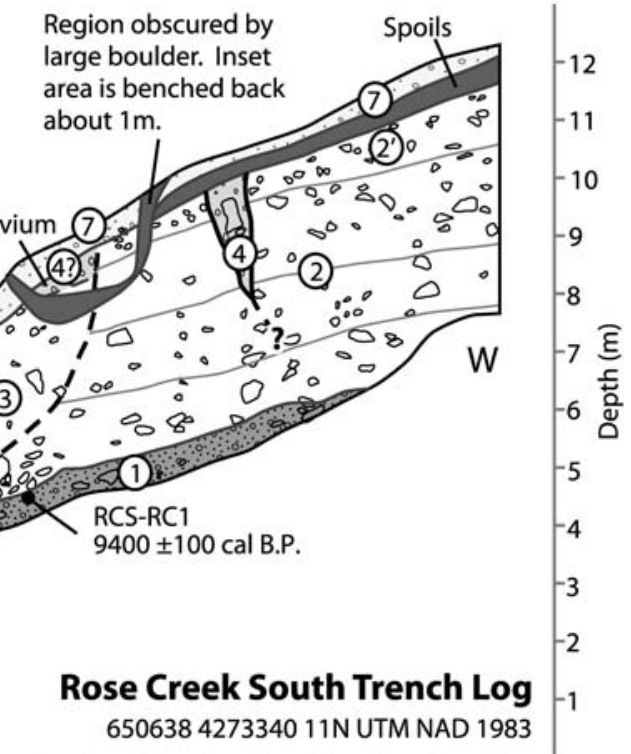

RCS-T1 \& T2

Samples from a reworked tephra

deposit that are regionally

correlated with Mono Craters

volcanism $600-2000{ }^{14} \mathrm{C}$ B.P.

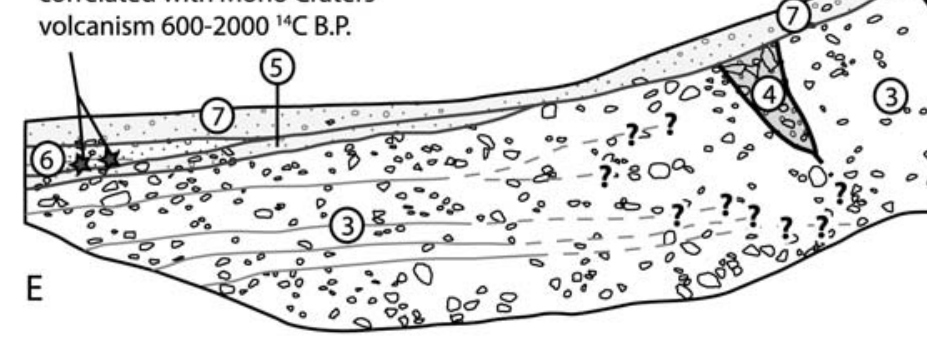


capped by a weakly developed Av horizon and become increasingly silt-rich adjacent to the fault. Subunit $6 \mathrm{a}$ is a waterlain, reworked tephra-bearing lens that overlies a charcoal-rich burn layer $\sim 0.15 \mathrm{~m}$ above the base of unit 6 . Tephra samples RCN-T1 and RCN-T2, taken from unit 6a, are assumed to share a similar origin with tephra exposures along the Wassuk Range that are correlated with late Holocene Mono Craters volcanism ( $\sim 600-2000{ }^{14}$ C yr B.P., Wesnousky, 2005; J. Bell, Nevada Bureau of Mines and Geology, Reno, Nevada, personal commun., 2010). Radiocarbon dating of charcoal samples from below and above the tephra layer constrains the timing of tephra deposition between $1460 \pm 70$ and $800 \pm 100$ cal B.P. (samples RCN-RC1 and RCN-RC15 in Fig. 3a and (E) Table S1 [available as an electronic supplement to this paper]; all radiocarbon ages are calibrated using Calib v. 6.0.1 [Stuiver and Reimer, 1993; Heaton et al., 2009; see the Data and Resources section]) and are reported with $2 \sigma$ uncertainties). The youngest unit in the trench, unit 7 , rests on the scarp face of fault strand A and is a wedge-shaped package of scarp-derived colluvium composed of tan, silty/sandy matrix-supported pebble gravels. Subunit $7^{\prime}$ is a small fissure filled with unit 7 gravels along the fault strand B. Unit 7 contains two distinct burn layers, depicted as dark gray lenses (Fig. 3a). Upslope from the fault, the matrix of unit 7 becomes more sand rich, reflecting an influx of fan material from a small alluvial cone at the base of the range front adjacent to the trench (Fig. 2). The cone alluvium covers the hanging wall fan surface (unit 3) near the trench and obscures the 1-m fault scarp.

We interpret the stratigraphy in the north trench exposure as resulting from three surface-rupturing earthquakes. The wedge-shaped unit 7 and fault-bounded subunit $7^{\prime}$ are interpreted to be scarp-derived colluvium and fissure fill resulting from the most recent movement (earthquake N1) on fault strands A and B (Fig. 3a). Vertical displacement for the N1 event, as estimated from the thickness of the colluvial wedge, is $\sim 1.0 \mathrm{~m}$-approximately the same height as the surficial scarp near the trench. Radiocarbon analysis of the youngest detrital charcoal sample taken from the upper portion of unit 6 , $\sim 0.3 \mathrm{~m}$ below the basal contact of unit 7, constrains the N1 event to occuring after $610 \pm 60$ cal B.P. (sample RCN-RC14 in Fig. 3a and in (E) Table S1 in the electronic supplement). Charcoal samples from the burn layer in unit 7 yield modern ages and thus are of limited utility in further constraining the age of faulting (samples RCN-RC10 and RCN-RC13 in Fig. 3a and in (E) Table S1 in the electronic supplement). Because there is no historical record of a surface-rupturing earthquake on the Wassuk Range after European settlement of the region, the age of the N1 earthquake is constrained between $610 \pm 60$ cal B.P. and A.D. $\sim 1850$.

The texture and shape of unit 5 are interpreted to be evidence of the penultimate earthquake (N2) recorded in the north trench. The upward-fining texture, wedge and fissure shape, and fault-bound contact with colluvial unit 2 indicate unit 5 is composed of colluvium shed off a scarp produced by slip on fault strand A. Unit 5 was subsequently displaced during the $\mathrm{N} 1$ event. We found no datable material below unit 5 , but the radiocarbon age of charcoal from the base of overlying alluvial unit 6 provides a minimum-limiting age of $1460 \pm 70$ cal B.P. for this event (sample RCN-RC1 in Fig. 3a and in (E) Table S1 in the electronic supplement). The vertical displacement for the $\mathrm{N} 2$ event is estimated to be at least $1.3 \mathrm{~m}$, based upon the thickness of unit 5 adjacent to fault strand A (Fig. 3a).

Evidence of an older earthquake (N3) in the north trench is recorded by the presence of a faulted colluvial wedge (unit 2) in the footwall and correlative fissure fill that is downdropped between fault strands $\mathrm{A}$ and $\mathrm{B}$. The presence of overlying debris-flow deposits (unit 3) indicates the N3 earthquake occurred during active aggradation of the fan surface. No datable material was located to constrain the age of this rupture. The thickness of unit 2 colluvium abutted to fault trace B suggests offset of greater than $1 \mathrm{~m}$ during the event.

\section{Rose Creek South Trench}

The Rose Creek south (RCS) trench crossed an $\sim 5.5 \mathrm{~m}$ scarp that cuts the Qy1 alluvial surface to the southeast of Rose Creek (Fig. 2). The 30-m-long trench exposed a thick package of coarse debris-flow and colluvial deposits (Fig. 3b). The oldest unit exposed in the trench (unit 1) is a debris-flow deposit capped by a 20-30-cm-thick, black, organic-rich, charcoal-bearing layer at the base of the trench. This unit is overlain by a thick package of matrix-supported, debris-flow deposits containing large angular boulders (unit 2). Slight reddening due to incipient soil development at the top of the $\sim 1$-m-thick flow deposits reveals a generally tabular fabric in the thick package. An eastward-dipping normal fault zone truncates footwall units 1 and 2 . The hanging wall deposits (unit 3) are similar in composition and texture to unit 2 . Reddening along contacts between individual sediment packages is evident in the easternmost portion of unit 3 , but we were unable to discern evidence of bedding in the central part of the trench near the fault zone. Where discernable, the $\sim 0.5-\mathrm{m}$ average bedding thickness in unit 3 is distinctly less than that observed in unit 2. Fissures filled with loose, reddish-brown sands and vertically aligned clasts (unit 4) cut units 2 and 3 . Unit 5 is a slope-wash deposit that overlies the eastern end of unit 3 and is buried by a fluvial, reworked tephra-bearing deposit (unit 6). Modern slopewash and aeolian deposits (unit 7) cap the entire exposure.

The coarse texture of unit 3 and lack of discernable bedding near the fault zone prevented us from determining a detailed earthquake chronology from this trench exposure. The composition and thickness of the deposit adjacent to the fault zone is consistent with an interpretation that much of unit 3 is fault-derived colluvium resulting from multiple earthquakes. The eastward gradation of unit 3 into distinct layers capped by incipient soil development may represent aggradation at the distal ends of colluvial wedges subsequent to individual earthquake offsets; however, this interpretation is complicated by the observation that the distal deposits 
appear to be emplaced by energetic debris-flow processes rather than colluvial deposition. The sediments preserved in unit 3 are likely a combination of colluvial and debris-flow deposits. We refrain from speculation about the discrete number of earthquakes recorded in unit 3.

We obtained few timing constraints on individual earthquakes in the south trench. Fissures (filled by unit 4) that cut units 2 and 3 and extend downward from the base of modern slope-wash deposits were formed during the most recent earthquake recorded in this trench (event S1). Unit 4? is a small colluvial deposit probably associated with the $\mathrm{S} 1$ earthquake, but this relationship is obscured by the presence of a large boulder in the trench wall. Radiocarbon dating of detrital charcoal found within a displaced soil block in the fissure fill yields a maximum age of $2810 \pm 50 \mathrm{cal}$ B.P. for the $\mathrm{S} 1$ earthquake (sample RCS-RC10 in Fig. $3 \mathrm{~b}$ and in (E) Table $\mathrm{S} 1$ in the electronic supplement). We assume the reworked-tephra deposit in the hanging wall of the south trench (unit 6 in Fig. 3b, samples RCS-T1 and RCS-T2) is similar to the Mono Craters tephra in the north trench that is constrained by radiocarbon dating to be deposited between $1460 \pm 70$ and $800 \pm 100$ cal B.P. The relative timing of deposition between the tephra (unit 6) and the S1 fissure deposits (unit 4) is ambiguous in this trench. We infer from the stratigraphic relationship between the $\mathrm{N} 1$ colluvium and the tephra layer in the north trench (unit 7 and subunit $6 \mathrm{a}$ in Fig. 3a, respectively) that the most recent displacement in the south trench (S1) occurred subsequent to tephra deposition. Deposition of the tephra postdates the formation of unit 3 . This observation places the minimum age of the penultimate (S2) and earlier earthquakes recorded by colluvial deposits within unit 3 at $>1460 \pm 70$ cal B.P. Unit 1 at the base of the footwall is the oldest exposed unit in the trench. A radiocarbon age of charcoal from the peatlike layer that caps unit 1 is $9400 \pm 100$ cal B.P. (sample RCS-RC1 in Fig. 3b and in (E) Table S1 in the electronic supplement).

\section{Holocene Slip Rate}

Topographic profiles across the fault scarp cutting the Qy1 fan surface show vertical separations adjacent to the south trench between 5 and $7 \mathrm{~m}$ (Fig. 2). Radiocarbon sample RCS-RC1 from the base of the hanging wall in the south trench (Fig. 3b) constrains the age of the fan surface to be less than $9400 \pm 100 \mathrm{cal}$ B.P. The stratigraphy in both the north and south trenches indicates that the vertical separation of the Qy1 surface results from multiple earthquakes. Dividing the maximum observed vertical separation of $7 \mathrm{~m}$ by $9400 \pm 100 \mathrm{yr}$ yields an estimate of Holocene vertical slip rate of $0.7 \mathrm{~mm} / \mathrm{yr}$. Uncertainty in the vertical separation measurement is on the order of $\pm 1 \mathrm{~m}$ because of slight differences in the slopes of the upper and lower surfaces. Accordingly, the uncertainty in the estimated slip rate is about $\pm 0.1 \mathrm{~mm} / \mathrm{yr}$.

\section{Penrod Canyon Alluvial Fan}

At the mouth of Penrod Canyon, Quaternary tectonic deformation is recorded by a fault scarp that truncates an abandoned alluvial fan surface (Fig. 4). The escarpment is etched with eroded wave-cut benches created during late Pleistocene pluvial lake highstands (Figs. 1 and 4) and strikes approximately $\mathrm{N} 30^{\circ} \mathrm{E}$ at a right step in the northnorthwest-striking range-front fault system (Fig. 1). The large escarpment cuts middle-to-late-Pleistocene fan and lacustrine platform veneer deposits (House and Adams, 2009) and is paralleled by 3-7-m Holocene fault scarps that offset the adjacent active fan surfaces (Fig. 4). The proximal location and parallel orientation of the young fault scarps relative to the wave-modified scarp support a predominantly tectonic origin of the large escarpment (Wesnousky, 2005). Topographic profiles across the larger scarp demonstrate minimum vertical separations of $30,40,41$, and $39 \mathrm{~m}$ (Fig. 4). Cross section $\mathrm{A}-\mathrm{A}^{\prime}$ is based on a profile from the highest elevation of the abandoned alluvial fan surface southeast across the escarpment to the active alluvial fan. At this location, $\sim 40 \mathrm{~m}$ of vertical relief is evident between the abandoned and active alluvial surfaces (Fig. 4), although the total vertical separation on the abandoned surface is greater due to an unknown amount of hanging wall burial by younger alluvium.

We sampled two large granitic boulders on the abandoned fan remnant (boulders 1 and 2 in Fig. 4; (E) boulder photos are available as an electronic supplement to this paper) to determine the length of time these rocks have been exposed to cosmogenic radiation on the fan surface (Gosse and Phillips, 2001). The Purdue Rare Isotope Measurement Laboratory (PRIME Lab of Purdue University) prepared the samples and measured the amounts of ${ }^{10} \mathrm{Be}$ and ${ }^{26} \mathrm{Al}$ in the rocks (Sharma et al., 2000). $\mathrm{BeO}$ and $\mathrm{Al}_{2} \mathrm{O}_{3}$ were purified from the quartz portion of the samples, following procedures developed by Kohl and Nishiizumi (1992). The ${ }^{10} \mathrm{Be}$ and ${ }^{26} \mathrm{Al}$ exposure ages we report were determined using the CRONUS-Earth online exposure age calculator, version 2.2 (Balco et al., 2008; see the Data and Resources section). Samples C1 and C2 were collected together and processed in the same batch. Sample CWL1 was collected and processed independently from the other samples. We calculated

${ }^{10} \mathrm{Be}$ and ${ }^{26} \mathrm{Al}$ exposure ages assuming no erosion for each of the samples. The individual ${ }^{10} \mathrm{Be}$ and ${ }^{26} \mathrm{Al}$ concentrations, model ages, and sample information are detailed in (E) Table S2 in the electronic supplement.

Samples C2 and CWL1 were collected from boulder 1 and yielded four age estimates, ${ }^{10} \mathrm{Be}$ ages of $84.5 \pm 1.7 \mathrm{ka}$ and $111.9 \pm 2.7 \mathrm{ka}$ and ${ }^{26} \mathrm{Al}$ ages of $108.8 \pm 4.8 \mathrm{ka}$ and $118.1 \pm 6.4 \mathrm{ka}$ for samples $\mathrm{C} 2$ and CWL1, respectively. Three of these four exposure ages agree to within the $1 \sigma$ analytical uncertainties, but the $\mathrm{C} 2{ }^{10} \mathrm{Be}$ age falls outside the $1 \sigma$ range. It is unusual for sample replicates from the same boulder to vary this much, especially given the concordance of the ${ }^{26} \mathrm{Al}$ results; however, there were no obvious problems 
(a)

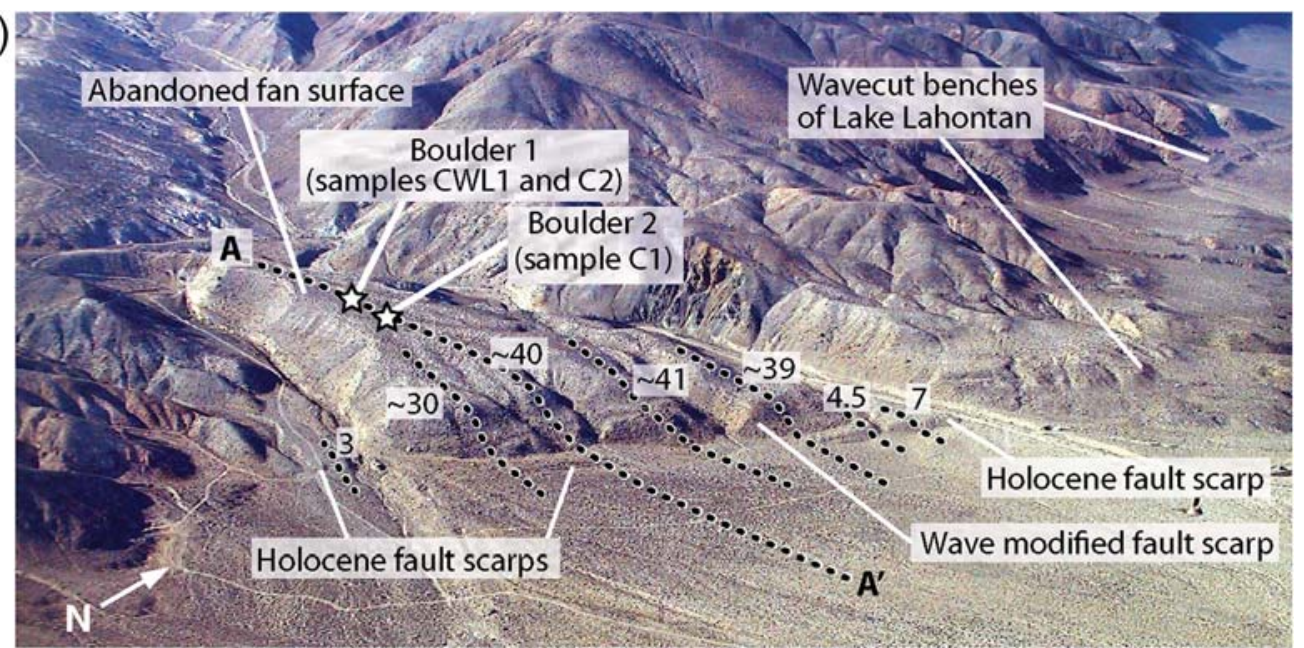

(b)

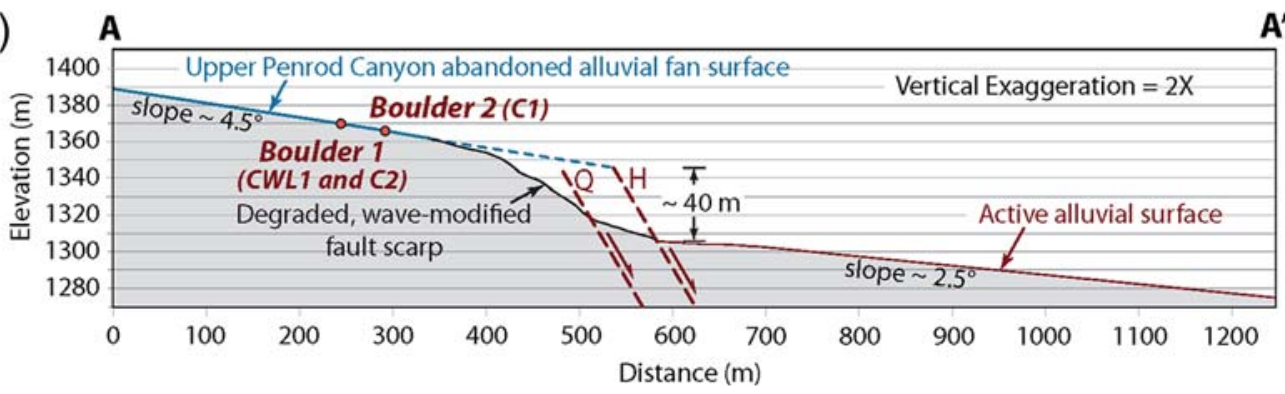

Figure 4. Penrod Canyon alluvial fan slip-rate site. See Figure 1 for location. (a) Photograph of the abandoned fan surface truncated by the Wassuk Range fault zone at the mouth of Penrod Canyon. Locations of boulders sampled for cosmogenic nuclide analysis are each marked with a white star. Numerical annotations indicate vertical separations measured from surveyed scarp profiles (dashed black lines). Location of illustrated scarp profile marked A-A'. Photograph modified from Wesnousky (2005). (b) Topographic profile across the 40-m, large, wave-modified fault scarp. Approximate locations of the Holocene $(\mathrm{H})$ and late Quaternary $(\mathrm{Q})$ fault traces are marked with dashed lines. The color version of this figure is available only in the electronic edition.

with the chemistry or the measurements. We sum the individual probability density functions to determine the mean age for boulder 1 and calculate the reduced $\chi^{2}$ statistic to determine the significance of the age groupings (e.g., Balco et al., 2009; Schaefer et al., 2009; Balco et al., 2011; Rood et al., 2011). Using all four C2 and CWL1 samples results in a mean age for boulder 1 with a $1 \sigma$ uncertainty of $105.8 \pm$ $13.5 \mathrm{ka}$ and reduced $\chi^{2}$ value of 26.5 . If the $\mathrm{C} 2{ }^{10} \mathrm{Be}$ age is excluded from the calculations, the resulting mean age of the three-sample set is $112.9 \pm 6.25 \mathrm{ka}$ with a reduced $\chi^{2}$ value of 0.785 (E) summary probability density function diagrams and statistics are available in the electronic supplement). The significantly lower reduced $\chi^{2}$ value of the three-sample age estimate gives us confidence in the three-sample grouping, and we use the age of $112.9 \pm 6.25 \mathrm{ka}$ for boulder 1. A third sample $\mathrm{C} 1$ was collected from boulder 2 downslope from boulder 1 . The ${ }^{10} \mathrm{Be}$ and ${ }^{26} \mathrm{Al}$ age estimates for boulder 2 (sample C1) are $75.7 \pm 1.7 \mathrm{ka}$ and $89.6 \pm 4.6 \mathrm{ka}$. These estimates do not agree to within the $1 \sigma$ analytical uncertainties. Samples $\mathrm{C} 1$ (boulder 2) and $\mathrm{C} 2$ (boulder 1) show ${ }^{26} \mathrm{Al} /{ }^{10} \mathrm{Be}$ production ratios that are higher than the accepted production ratio of 6.75 (Nishiizumi et al., 2007). Because samples C1 and $\mathrm{C} 2$ were analyzed at the same time and the sample $\mathrm{C} 2$
${ }^{10} \mathrm{Be}$ age estimate is significantly lower than the other three concordant boulder 1 age estimates, we conclude that the sample $\mathrm{C} 1$ (boulder 2) ${ }^{10} \mathrm{Be}$ age estimate may also be anomalously low. Accordingly, we use the ${ }^{26} \mathrm{Al}$ age of $89.6 \pm 4.6 \mathrm{ka}$ as the exposure age of boulder 1 .

Although the ages of boulders 1 and $2(112.9 \pm 6.25 \mathrm{ka}$ and $89.6 \pm 4.6 \mathrm{ka}$, respectively) are not in tight agreement, it is not unusual to see spread in boulder age estimates for depositional features of this age (e.g., Heyman et al., 2011; Rood et al., 2011). Geological processes such as weathering, exhumation, and shielding of surfaces by sediment or snow will lead to exposure ages that are younger than the true age of the landform (e.g., Heyman et al., 2011; Owen et al., 2011). Recognizing that our ages are minimum estimates due to the assumption of zero erosion on the boulders and the small sample size ( $n=2$ boulders), we interpret the oldest boulder age of $112.9 \pm 12.5$ ka with $2 \sigma$ uncertainty (boulder 1, sample C2/CWL1) as the best estimate of the depositional age of the fan surface.

\section{Late Pleistocene Slip Rate}

The vertical offset and exposure age data permit an estimate of a time-averaged late Pleistocene vertical slip rate 
along the Wassuk Range fault zone. Dividing the 40-m minimum vertical separation measurement by our fan surface depositional age estimate of $112.9 \pm 12.5$ ka yields an initial estimate of the minimum late Pleistocene vertical slip rate at greater than $0.3-0.4 \mathrm{~mm} / \mathrm{yr}$. Uncertainties in both the separation measurements (due to an unknown amount of hanging wall burial) and age of the displaced surface (due to the small number of boulders sampled) preclude a more precise calculation of the longer-term slip rate on the rangefront fault.

\section{Discussion and Conclusions}

Observations from the Rose Creek trenches provide new information on the timing and size of Holocene surfacerupturing earthquakes on the Wassuk Range fault zone. Both trench exposures record multiple Holocene earthquakes, although the unique correlation of individual events between the two trenches is ambiguous. The north trench exposure records a most recent event (N1) displacement of $\sim 1 \mathrm{~m}$ between $610 \pm 60 \mathrm{cal}$ B.P. and A.D. 1850, a penultimate event (N2) with $>1.3 \mathrm{~m}$ of displacement prior to $1460 \pm 70 \mathrm{cal}$ B.P., and an older undated displacement (N3). The south trench exposure defines a single discrete event (S1) that postdates $2810 \pm 50 \mathrm{cal}$ B.P. and, by inference from the north trench, also postdates deposition of the Mono Craters tephra layer that was deposited between $800 \pm 100$ and $1460 \pm 70$ cal B.P. Interpretation of the south trench also results in recognition that multiple offsets (earthquake $\mathrm{S} 2$ and prior events) produced a thick colluvial package (unit 3; Fig. 3b) between $1460 \pm 70$ and $9400 \pm 100$ cal B.P. Because of the proximity of the two trenches, it seems likely that the trenches share a similar earthquake history. The interpreted earthquake histories for both trenches are consistent with a most recent event (N1 and S1) occurring between $610 \pm 60$ cal B.P. and A.D. 1850 and a penultimate event (N2 and S2) occurring prior to $1460 \pm 70 \mathrm{cal}$ B.P. and deposition of the Mono Craters tephra. Colluvial wedge thicknesses from the north trench suggest a Holocene per event displacement of $>1 \mathrm{~m}$. Our observations support the geomorphic interpretation by Demsey (1987) that the Rose Creek fan head scarps record multiple Holocene earthquakes.

Holocene fault scarps of 2-6 m cut active and young fan deposits along the entire length of the Wassuk Range (Demsey, 1987; Wesnousky, 2005). Our observations at Rose Creek show the occurrence of at least three Holocene earthquakes with a minimum per event displacement of $>1 \mathrm{~m}$. It is thus likely that many of the scarps previously mapped along the range front (e.g., Wesnousky, 2005) are multiple-event scarps. The earthquake timing and size observations from Rose Creek fan do not provide sufficient information to estimate the length and location of past ruptures.

We report estimates of vertical slip rate that range from a late Pleistocene rate of $>0.3-0.4 \mathrm{~mm} / \mathrm{yr}$ at Penrod Canyon to a Holocene rate of $0.7 \pm 0.1 \mathrm{~mm} / \mathrm{yr}$ at Rose Creek. The spread of values reflects the study of two sites separated by $\sim 30 \mathrm{~km}$ and rates averaged over times spanning $\sim 113 \mathrm{ka}$ and less that $10 \mathrm{ka}$, respectively. Observations are not sufficient to determine whether the difference in the slip rates reflects the spatial variation of slip accumulation or a temporal variation in slip rate. The caveat should be recognized when applying the reported slip rates to problems in seismic hazard or tectonics. The bounding rates of $0.3-0.8 \mathrm{~mm} / \mathrm{yr}$ overlap with the post-Pliocene Wassuk Range time-averaged uplift rate of $0.5-0.75 \mathrm{~mm} / \mathrm{yr}$ (Stockli et al., 2002) and are consistent with a previous Holocene vertical slip-rate estimate of $0.4-0.5 \mathrm{~mm} / \mathrm{yr}$ based on fault-zone geomorphology (Demsey, 1987). Thus, with evidence of at least three Holocene surface-rupturing earthquakes and Holocene-late Pleistocene vertical slip rates between 0.3 and $0.8 \mathrm{~mm} / \mathrm{yr}$, we conclude the Wassuk Range fault zone is a significant source of seismic hazard in the central Walker Lane.

\section{Data and Resources}

All data used in this paper were collected during the duration of this study or came from published sources listed in the references and the U.S. Geological Survey, Nevada Bureau of Mines and Geology, and the California Geological Survey (2006) Quaternary fault and fold database for the United States (http://earthquake.usgs.gov/regional/qfaults/; last accessed January 2008). The Calib program for radiocarbon age calibration (Stuiver and Reimer, 1993; Heaton et al., 2009) is available at Calib http://calib.qub.ac.uk/calib/; last accessed November 2010. The CRONUS-Earth online exposure age calculator (Balco et al., 2008) can be accessed at CRONUS-Earth http://hess.ess.washington.edu/math/; last accessed June 2011.

\section{Acknowledgments}

We are grateful to the Hawthorne Army Depot and John Peterson for allowing us access to the Rose Creek site. We thank Michael Lazaro in the Navy Geothermal Program Office for facilitating the Rose Creek trenching permit. This manuscript benefitted from thoughtful comments from Steve Personius and an anonymous reviewer. Thanks to Alex Sarmiento for field assistance and many insightful comments. Thank you to John Bell for helpful conversation regarding the age of faulting along the Wassuk Range and to Kyle House for sharing his wealth of knowledge regarding the use of LiDAR data. Thanks also to Rich Briggs, Ryan Gold, Tony Crone, Alan Ramelli, R. Jayangondaperumal, Ricardo Civico, Joanna Redwine, and the participants of the 2010 Pacific Cell Friends of the Pleistocene field trip for valuable discussion, observations, and questions that further refined this research. Rich Koehler read an early draft of this manuscript and provided many insightful suggestions. This work was supported by the National Science Foundation grant EAR-0635757 as part of the EarthScope project. This manuscript is Center for Neotectonic Studies Contribution number 62.

\section{References}

Adams, K. D., and S. G. Wesnousky (1999). The Lake Lahontan highstand: Age, surficial characteristics, soil development, and regional shoreline correlations, Geomorphology 30, 357-392.

Balco, G. (2011). Contributions and unrealized potential contributions of cosmogenic-nuclide exposure dating to glacier chronology, 1990-2010, Quaternary Sci. Rev. 30, 3-27. 
Balco, G., J. Briner, R. C. Finkel, J. A. Rayburn, J. C. Ridge, and J. M. Schaefer (2009). Regional beryllium-10 production rate calibration for late-glacial northeastern North America, Quaternary Geochronol. 4, 93-107.

Balco, G., J. O. Stone, N. A. Lifton, and T. J. Dunai (2008). A complete and easily accessible means of calculating surface exposure ages or erosion rates from 10Be and 26Al measurements, Quaternary Geochronol. 3, 174-195.

Bennett, R. A., B. P Wernicke, N. A. Niemi, A. M. Friedrich, and J. L. Davis (2003). Contemporary strain rates in the northern Basin and Range Province from GPS data, Tectonics 22, 1008, doi 10.1029/ $2001 \mathrm{TC} 001355$

Briggs, R. W., and S. G. Wesnousky (2004). Late Pleistocene fault slip rate, earthquake recurrence, and recency of slip along the Pyramid Lake fault zone, northern Walker Lane, United States, J. Geophys. Res. 109, no. B08402, doi 10.1029/2003JB002717.

Demsey, K. (1987). Holocene faulting and tectonic geomorphology along the Wassuk Range, west-central Nevada. Master's Thesis, University of Arizona, Tucson, $64 \mathrm{pp}$.

Dilles, J. H. (1993). Cenozoic and normal and strike-slip faults in the northern Wassuk Range, western Nevada, in Structure, Tectonics, and Mineralization of the Walker Lane, Walker Lane Symposium Proceedings, Reno, Nevada, S. D. Craig (Editor), Geol. Soc. Nevada, 114-136.

Gosse, J. C., and F. M. Phillips (2001). Terrestrial in situ cosmogenic nuclides: Theory and application, Quaternary Sci. Rev. 20, $1475-1560$

Hammond, W. C., and W. Thatcher (2007). Crustal deformation across the Sierra Nevada, northern Walker Lane, Basin and Range transition, western United States measured with GPS, 2000-2004, J. Geophys. Res. 112, no. B05411, doi 10.1029/2006JB004625.

Heaton, T. J., P. G. Blackwell, and C. E. Buck (2009). A Bayesian approach to the estimation of radiocarbon calibration curves: The IntCal09 methodology, Radiocarbon 51, 1151-1164.

Heyman, J., A. P. Stroeven, J. M. Harbor, and M. W. Caffee (2011). Too young or too old: Evaluating cosmogenic exposure dating based on an analysis of compiled boulder exposure ages, Earth Planet. Sci. Lett. 302, 71-80.

House, P. K., and K. D. Adams (2009). Preliminary geologic map of the southern part of the lower Walker River area, Mineral County, Nevada, scale 1:24,000, Nevada Bureau Mines Geol. Open-File Rept. 09-13.

Kohl, C. P., and K. Nishiizumi (1992). Chemical isolation of quartz for measurement of in situ-produced cosmogenic nuclides, Geochim. Cosmochim. Acta 56, 3583-3587.

Nishiizumi, K., M. Imamura, M. W. Caffee, J. R. Southon, R. C. Finkel, and J. McAninch (2007). Absolute calibration of 10Be AMS standards, Nucl. Instrum. Methods B 258, 403-413.

Oldow, J. S. (2003). Active transtensional boundary zone between the western Great Basin and Sierra Nevada block, western US Cordillera, Geology 31, 1033-1036.

Oldow, J. S., C. L. V. Aiken, J. F. Ferguson, J. L. Hare, and R. F. Hardyman (2001). Active displacement transfer and differential motion between tectonic blocks within the central Walker Lane, western Great Basin, Geology 29, 19-22.

Owen, L. A., K. L. Frankel, J. R. Knott, S. Reynhout, R. C. Finkel, J. F. Dolan, and J. Lee (2011). Beryllium-10 terrestrial cosmogenic nuclide surface exposure dating of Quaternary landforms in Death Valley, Geomorphology 125, 541-557.

Rood, D. H., D. W. Burbank, and R. C. Finkel (2011). Chronology of glaciations in the Sierra Nevada, California, from 10Be surface exposure dating, Quaternary Sci. Rev. 30, 646-661.
Schaefer, J. M., G. H. Denton, M. Kaplan, A. Putnam, R. C. Finkel, D. J. A. Barrell, B. G. Andersen, R. Schwartz, A. Mackintosh, T. Chinn, and C. Schluchter (2009). High-frequency Holocene glacier fluctuations in New Zealand differ from the northern signature, Science 324, 622-625.

Sharma, P., M. Bourgeois, D. Elmore, D. Granger, M. E. Lipschutz, X. Ma, T. Miller, K. Mueller, G. Rickey, P. Simms, and S. Vogt (2000). PRIME Lab AMS performance, upgrades and research applications, Nucl. Instrum. Methods B 172, 112-123.

Smith, J. L. (2008). Digital elevation model of Walker Lake, westcentral Nevada, http://water.usgs.gov/lookup/getspatial?sir2007-5012 bathymetry, in Bathymetry of Walker Lake, West-Central Nevada: U.S. Geological Survey Scientific Investigations Report 2007-5012, T. J. Lopes and J. L. Smith (Editor), 25 pp. http://pubs.usgs.gov/sir/ 2007/5012/ (last accessed, March 2009).

Stockli, D. F., B. E. Surpless, and T. A. Dumitru (2002). Thermochronological constraints on the timing and magnitude of Miocene and Pliocene extension in the central Wassuk Range, western Nevada, Tectonics 21, doi 10.1029/2001TC001295.

Stuiver, M., and P. J. Reimer (1993). Extended 14C database and revised CALIB 6.0 radiocarbon calibration program, Radiocarbon 35, 215230.

Surpless, B. E. (2008). Modern strain localization in the central Walker Lane, western United States: Implications for the evolution of intraplate deformation in transtensional settings, Tectonophysics 457, 238-253.

Surpless, B. E. (2011). Cenozoic tectonic evolution of the central Wassuk Range, western Nevada, USA, Int. Geol. Rev. 54, 547-571, doi 10.1080/00206814.2010.548117.

Surpless, B. E., D. F. Stockli, T. A. Dumitru, and E. L. Miller (2002). Twophase westward encroachment of Basin and Range extension into the northern Sierra Nevada, Tectonics 21, doi 10.1029/2000TC001257.

Thatcher, W., G. R. Foulger, B. R. Julian, J. Svarc, E. Quilty, and G. W. Bawden (1999). Present-day deformation across the Basin and Range Province, western United States, Science 283, 17141718, doi 10.1126/science.283.5408.1714.

Wesnousky, S. G. (2005). Active faulting in the Walker Lane, Tectonics 24, TC3009, doi 10.1029/2004TC001645.

Center for Neotectonic Studies

University of Nevada, Reno

Reno, Nevada 89557

jbormann@unr.edu

(J.M.B., S.G.W.)

Department of Geosciences

Trinity University

One Trinity Place

San Antonio, Texas 78212-7200

(B.E.S.)

Department of Physics

Purdue Rare Isotope Measurement Laboratory

Purdue University

525 Northwestern Avenue

West Lafayette, Indiana 47907-2036

(M.W.C.)

Manuscript received 7 October 2011 